\title{
Pengembangan Media Pembelajaran Scrapbook Dongeng Fabel Terhadap Minat Literasi siswa SD
}

\author{
Inggrid Dwi Cahyani1 ${ }^{*}$, Lukman Nulhakim², Rina Yuliana ${ }^{3}$
}

1,2,3 Jurusan Pendidikan Guru Sekolah Dasar, Universitas Sultan Ageng Tirtayasa, Banten, Indonesia

\section{ART I CLE IN F O}

Article history:

Received May 03, 2021

Revised May 05, 2021

Accepted June 10, 2021

Available online July 25, 2021

\section{Kata Kunci:}

Scrapbook, Dongeng Fabel, litetasi, Media

\section{Keywords:}

Scrapbook, Fables, literacy, Media

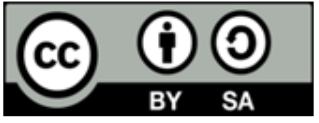

This is an open access article under the CC BY-SA license.

Copyright (ㅇ) 2021 by Author. Published by Universitas Pendidikan Ganesha.

\begin{abstract}
A B S T R A K
Literasi sangat perlu dikembangkan sejak siswa masih berada pada jenjang pendidikan dasar, apalabi saat ini kemapuan literasi siswa SD sangat lemah yang menuntut guru harus mampu membelajarakan siswa dengan dengan baik. Penelitian ini bertujuan untuk mengembangkan Scrapbook Dongeng Fabel. Metode penelitian yang digunakan adalah R\&D (Research and Development) dengan desain penelitian milik Borg dan Gall yang dimodifikasi oleh Sugiyono. Subjek penelitian ini adalah 11 Orang siswa SD, ahli materi, ahli media dan ahli praktisi. Metode pengumpulan data yang diagunkan adaalah angket. Hasil penelitian ini adalah media pembelajaran Scrapbook dongeng fabel terhadap minat literasi baca tulis siswa SD. Berdasarkan hasil uji kelayakan terhadap ahli media diperoleh kriteria sangat layak dengan nilai rata-rata sebesar $84,5 \%$. Hasil validasi oleh ahli materi memperoleh kriteria sangat layak dengan nilai rata-rata sebesar $84 \%$. Hasil validasi oleh ahli bahasa memperoleh kriteria layak dengan nilai rata-rata sebesar $74,15 \%$. Adapun hasil angket respons siswa pada uji coba terbatas memperoleh nilai rata-rata sebesar $93,3 \%$ dengan kriteria sangat baik. Berdasarkan hasil tersebut, media Scrapbook Dongeng Fabel dinyatakan layak untuk digunakan dalam kegiatan pembelajaran siswa kelas II SD.
\end{abstract}

\section{A B S T R A C T}

Literacy really needs to be developed since the elementary education level, especially at this time the literacy skills of elementary school students are very weak which requires teachers to be able to teach students well. This study aims to develop a Fable Scrapbook. The research method used is R\&D (Research and Development) with Borg and Gall's research design modified by Sugiyono. The subjects of this study were 11 elementary school students, material experts, media experts and practitioners. The data collection method used as collateral is a questionnaire. The result of this research is the fable tale Scrapbook learning media on the literacy interest of elementary school students. Based on the results of the feasibility test on media experts, the criteria were very feasible with an average value of $84.5 \%$. The results of the validation by material experts obtained very feasible criteria with an average value of $84 \%$. The results of validation by linguists obtained appropriate criteria with an average value of $74.15 \%$. The results of the student response questionnaire in the limited trial obtained an average score of $93.3 \%$ with very good criteria. Based on these results, the Fable Fable Scrapbook media was declared feasible to be used in the learning activities of second grade elementary school students.

\section{PENDAHULUAN}

Literasi di Indonesia saat ini tergolong cukup rendah, hal tersebut dikarenakan kurangnya akses membaca seperti perpustakan keliling terutama di daerah pedesaan. Selain itu minimnya perpustakan juga terjadi di sekolah-sekolah yang kurang maju atau sekolah yang masih terakreditasi C. Literasi sangat perlu dikembangkan sejak siswa masih berada pada jenjang pendidikan dasar, karena literasi merupakan sebuah bentuk kegiatan untuk menafsirkan segala bentuk ilmu untuk membuat seseorang memiliki pengetahuan yang lebih luas (Pratiwi, 2021; Susanto, 2016). Literasi terdiri atas enam jenis, yaitu literasi baca tulis, literasi numerasi, literasi sains, literasi budaya dan kewargaan, literasi digital, dan literasi finansial (Sadli \& Saadati, 2019; Setiawan \& Sudigdo, 2019). Adapun pengertian dari masing-masing literasi tersebut yaitu: Pertama, literasi baca tulis merupakan kemampuan seseorang dalam membaca dan menulis untuk mengetahui, menelusuri, menganalisis, menanggapi dan masih banyak lagi untuk mencapai suatu tujuan sehingga mampu mengembangkan potensi diri menjadi lebih baik (Indriyani et al., 2019; Suandewi et al., 2019). Kedua, literasi 
numerasi merupakan kemampuan dalam menghitung dan mengaplikasikan operasi hitung baik itu dalam pembelajaran maupun kehidupan sehari-hari. Kemampuan literasi numerasi juga dipakai untuk menerjemahkan data kuantitatif yang berada di sekitar kita (Ratnasari, 2020; Wijaya et al., 2016). Ketiga, literasi sains merupakan kemampuan untuk mengidentifikasi terkait isu-isu yang bersifat multidimensional, artinya bukan hanya pemahaman mengenai sains saja, melainkan lebih dari itu (Fiangga et al., 2019; Pangesti, 2018). Keempat, literasi budaya dan kewargaan merupakan kemampuan seseorang atau individu untuk bersikap terhadap lingkungan sekitarnya sebagai bagian dari budayanya masing-masing ( dwi arum Sari \& Supriyadi, 2021; Yusuf et al., 2020). Kelima, literasi digital merupakan literasi untuk mengakses informasi dalam mengembangkan suatu pengetahuan agar dapat berpartisipasi dengan seseorang di seluruh belahan dunia (Setyaningsih et al., 2019). Kelima, Literasi finansial merupakan kemampuan seseorang dalam memahami konsep serta resiko untuk mengambil sebuah keputusan secara efektif baik itu dari individu maupun kelompok masyarakat (Nurhab, 2018). Keberhasilan siswa dalam mengembangkan kemampuan literasinya tidak terlepas dari minat siswa sendiri.

Minat belajar sangat dibutuhkan dalam proses pembelajaran, minat merupakan dorongan dari dalam diri anak untuk berpartisipasi aktif dalam proses pembelajaran sehingga dapat mengubah atau menambah pengetahuan dan pengalaman (Nasution et al., 2020) Minat belajar merupakan faktor yang sangat penting dalam mencapai kesuksesan di segala bidang seperti sepeti studi, kerja, hobi, maupun aktivitas (Chen et al., 2020). Minat bukan hanya sekedar rasa suka akan sesuatu atau aktivitas (Utomo et al., 2018). Minat belajar yang ada pada siswa mempunyai fungsi sebagai kekuatan yang mendorong siswa untuk belajar. Semakin tinggi minat siswa akan aktivitas akan membuat siswa semakian baik dalam proses belajarnya yang akan berdampak terhadap tercapainya tujuan yang diinginkan(Pambudi, 2018). Meningkatkan minat belajar siswa bisa mengunkan media pembelajaran, minat belajar anak akan lebih tinggi jika menggunakan media yang dirasa lebih menarik dan menyenangkan bagi anak(Ayuningtyas \& Wijayaningsih, 2020). Media pembelajaran adalah salah satu sarana yang bisa digunakan sebagai sarana meningkatkan minat siswa dalam proses pembelajaran. Oleh sebab itulah sangat penting bagi guru untuk menggunkan media pembelajaran. Namun pada kenyataannya literasi membaca bukanlah budaya masyarakat Indonesia, mengingat masih banyak daerah di Indonesia dengan minat baca tulis yang rendah alhasil kemampuan literasinya juga rendah (Muslimin, 2018). Berdasarkan hasil analisis kebutuhan yang telah dilaksanakan di kelas II SDN Karundang 2 Kota Serang, melalui observasi dan wawancara yang dilakukan bersama dengan wali kelas, peneliti menenukan fakta bahwa siswa terlihat kurang bersemangat ketika belajar dikarenakan pembelajaran masih berorientasi pada guru yang hanya berpaku pada buku paket dan model pembelajaran cenderung sama dalam setiap pertemuan sehingga ketertarikan siswa dalam belajar berkurang, terutama pada pelajaran cerita guru cenderung hanya terpaku pada buku-buku paket yang tersedia padahal SDN Karundang 2 memiliki perpustakaan, namun karena keterbatasan ruangan sehingga perpustakaan berubah menjadi ruang guru. Selain itu, ketersediaan buku-buku bacaan sangatlah minim sehingga perlu adanya pengadaan ruangan dan pengadaan buku-buku yang dapat memotivasi siswa dalam membangun minat literasi baca tulis pada siswa sejak dini. Maka dengan itu perlu adanya suatu tindakan untuk menanggulkangi minat literasi pada siswa.

Upaya yang dapat dilakukan untuk mengatasi permasalahan tersebut adalah dengan menetapkan alternative pemecahan masalah dengan mengembangkan media pembelajaran inovatif berupa buku Scrapbook Dongeng Fabel guna menarik minat literasi siswa dalam membaca dan menulis. Pengembangan media yang dapat meningkatkan kemampuan literasi siswa serta dapat meningkatkan motivasi siswa dalam belajar adalah berupa media Scrapbook berbasis soal literasi. Media Scrapbook merupakan media pembelajaran visual, karena dalam media Scrapbook menampilkan sebuah gambar untuk menarik minat baca siswa. Media visual sangat penting dibelajarkan kepada siswa dengan fungsi dapat memperlancar pemahaman dan memperkuat ingatan pada materi yang telah dibelajarkan oleh guru. Media pembelajaran yang unik dan menarik dibutuhkan untuk menumbuhkan minat literasi siswa yaitu dengan menggunakan media Scrapbook. Scrapbook merupakan salah satu seni menempel hiasan di atas kertas kemudian menghiasnya dengan karya yang kreatif (Rosihah \& Pamungkas, 2018; Saeful, 2017). Media Scrapbook sangat tepat diterapkan dalam pembelajaran, karena media Scrapbook meningkatkan keaktifan siswa dalam belajar sehingga akan menghasilkan suatu pembelajaran yang baik dan optimal (Alfiah et al., 2018; Sari et al., 2020), media scrapbook melibatkan siswa secara langsung dalam proses belajar(Nurdiana \& Murjainah, 2018). Penelitian ini sejalan dengan penelitian yang menyatakan bahwa Scrapbook merupakan sebuah media pembelajaran yang menggunakan teknik tempel guna menarik minat siswa dalam belajar (Utaminingsih et al., 2019). Penelitian serupa juga sejalan dengan penelitian yang menyatakan bahwa media pembelajaran Scrapbook disajikan dengan berisi materi-materi serta hiasan-hiasan guna menarik perhatian siswa, sehingga merangsang keinginan siswa dalam belajar (Suwandi, 2018). Pada penelitian ini Scrapbook yang dikembangkan adalah Scrapbook Dongeng Fabel yang dikemas menjadi sebuah buku tempel yang unik dan menarik untuk dibaca, sehingga terciptanya kegiatan literasi yang menyenangkan karena dilakukan dengan bermain kreatif yang dimuat dalam media scrapbook tersebut. Kreatifitas yang dimuat dalam buku akan mendorong siswa untuk tertarik membacanya, hal ini menunjukan bahwa media pembelajaran Scrapbook sangat efektif digunakan khususnya dalam melatih siswa untuk mampu mengembangkan 
kreatifitasnya terutama dalam berbahasa seperti membaca dan menulis. Dengan adanya media pembelajaran Scrapbook juga dapat melatih siswa dalam berkomunikasi, bersosialisasi, serta dapat juga digunakan sebagai alat ukur untuk melihat ketertarikan siswa pada dunia literasi baca tulis.

\section{METODE}

Desain penlitian yang digunakan dalam penelitian ini adalah model penelitian dan pengembangan (reasearch \& development). Penelitian dan pengembangan merupakan ujung tombak dari industry dalam menghasilkan produk-produk baru (Hanafi, 2017). Penelitian dilakukan di SDN Karundang 2 Kota Serang, Provinsi Banten. Alasan peneliti memilih sekolah ini karena SDN Karundang 2 merupakan sekolah yang menggunakan kurikulum 2013 sehingga memudahkan peneliti dalam mendapatkan informasi yang diperlukan, mengingat kurikulum 2013 seharusnya telash menerapkan Gerakan literasi. Penelitian ini akan dilakukan pada semester ganjil tahun ajaran 2020/2021 di kelas II-B yang berlangsung selama 1 bulan. Dengan siswa yang berjumlah 11 orang. Adapun langkah-langkah penelitian dan pengembangan yang telah disesuaikan dengan penelitian yakni (a) Potensi dan masalah, (b) Pengumpulan informasi, (c) Desain produk, (d) Validasi desain, (e) Revisi desain, (f) Uji coba produk. Intrumen yang digunakan pada penelitian ini adalah angket sebagai alat untuk mendapatkan data tetang kelayakan produk media Srapbook Dongeng Fabel. Ada empat macam angket yang digunakan pada penelitian ini yaitu angket validasi ahli media, angket validasi ahli materi, angket validasi ahli bahasa dan anglet repon siswa. Kisi-kisi angket yang digunakan dalam penelitian dan pengembangan produk media Scrapbook Dongeng Fabel dalam melihat minat literasi siswa ditunjukkan pada table 1,2,3 dan 4 .

Tabel 1. Kisi-Kisi Instrumen Ahli Media

\begin{tabular}{|c|c|c|c|}
\hline Aspek & Komponen & Indikator Komponen & Nomor Butir \\
\hline \multirow{11}{*}{$\begin{array}{l}\text { Kelayakan } \\
\text { Kegrafikan }\end{array}$} & Ukuran Media & Ukuran Fisik & $1,2,3,4$ \\
\hline & Desain scrapbook & Kemenarikan bentuk media & 5 \\
\hline & & Kemenarikan Warna dan permainan pada media & \\
\hline & Ukuran Media & & 6 \\
\hline & & Konsistensi tata letak & 7 \\
\hline & & Unsur tata letak harmonis. & 8 \\
\hline & & Unsur tata letak lengkap. & 9,10 \\
\hline & & Tata letak yang harmonis mempercepat & 11 \\
\hline & Tata Letak & Tifografi mudah dibaca. & $\begin{array}{l}11 \\
12\end{array}$ \\
\hline & & Lugas. & 13,14 \\
\hline & & Komunikatif. & 15 \\
\hline \multirow{6}{*}{$\begin{array}{l}\text { Aspek } \\
\text { Kelayakan } \\
\text { Bahasa }\end{array}$} & & Dialogis dan interaktif. & 16 \\
\hline & & Kesesuaian dengan perkembangan peserta didik. & \\
\hline & Penggunaan bahasa & & 17 \\
\hline & pada media & Kesesuaian dengan kaidah bahasa. & 18 \\
\hline & & Penggunaan istilah, simbol atau ikon. & \\
\hline & & & 19 \\
\hline
\end{tabular}

Tabel 2. Kisi-Kisi Instrumen Ahli Materi

\begin{tabular}{llc}
\hline \multicolumn{1}{c}{ Aspek } & \multicolumn{1}{c}{ Indikator } & $\begin{array}{c}\text { Nomor } \\
\text { Butir }\end{array}$ \\
\hline Kelayakan Isi & Kesesuaian materi dengan KI dan KD & 1 \\
& Keakuratan Materi & 2 \\
Keakuratan materi & Kelengkapan materi & $3,4,5,6$ \\
Pendukung materi & Keterkaitan materi pembelajaran & $7,8,9,10,11$ \\
pembelajaran & & 12,13 \\
Aspek Kelayakan Materi & Pendukung penyajian & $14,15,16$ \\
& Kelengkapan penyajian & \\
\hline
\end{tabular}

Tabel 3. Kisi-Kisi Instrumen Ahli Bahasa

\begin{tabular}{llr}
\hline Aspek & Indikator & Nomor Butir \\
\hline & Keterbacaan & $1,2,3$ \\
& Kejelasan Informasi & $4,5,6$ \\
& Kesesuaian dengan kaidah Bahasa &
\end{tabular}




\begin{tabular}{clc}
\hline \multicolumn{1}{c}{ Aspek } & \multicolumn{1}{c}{ Indikator } & Nomor Butir \\
\hline \multirow{3}{*}{ Aspek Kebahasaan } & Indonesia yang baik dan benar & $7,8,9$ \\
& $\begin{array}{l}\text { Pemanfaatan bahasa secara efektif dan } \\
\text { efesien. }\end{array}$ & $10,11,12$ \\
\hline
\end{tabular}

Tabel 4. Kisi-Kisi Angket Respon Siswa (Minat Literasi)

\begin{tabular}{|c|c|c|}
\hline Aspek & Indikator & Nomor Butir \\
\hline Pemusatan Perhatian & $\begin{array}{l}\text { Mampu melaksanakan pembelajaran } \\
\text { secara aktif dan fokus. }\end{array}$ & $2,13,14$ \\
\hline $\begin{array}{l}\text { Keterlibatan dan } \\
\text { Penggunaan waktu }\end{array}$ & $\begin{array}{l}\text { Mampu terlibat dan menggunakan waktu } \\
\text { secara efektif dalam pembelajaran. }\end{array}$ & $5,10,12$ \\
\hline $\begin{array}{l}\text { Motivasi dan Usaha untuk } \\
\text { membaca }\end{array}$ & $\begin{array}{l}\text { Usaha siswa dalam memiliki maupun } \\
\text { membaca buku. }\end{array}$ & 6,9 \\
\hline Emosi dalam membaca & $\begin{array}{l}\text { Mampu memberikan tanggapan terhadap } \\
\text { buku bacaan tanpa rasa terpaksa. }\end{array}$ & $3,8,15$ \\
\hline $\begin{array}{l}\text { Ketertarikan Kesukaan } \\
\text { dalam membaca }\end{array}$ & $\begin{array}{l}\text { Perasaan Senang dan ketertarikan siswa } \\
\text { pada pembelajaran menggunakan media } \\
\text { Scrapbook. }\end{array}$ & $1,4,7,11$ \\
\hline
\end{tabular}

\section{HASIL DAN PEMBAHASAN}

\section{Hasil}

Hasil penelitian ini diperoleh setelah peneliti melakukan tahapan uji validitas terhadap tim ahli dan uji coba di lapangan secara terbatas kepada siswa SDN Karundang 2 kelas II-B Kota Serang. Berdasarkan data pertama, hasil validasi media menunjukkan bahwa diperoleh persentase nilai rata-rata sebesar $84,5 \%$ dari kedua ahli, maka dapat disimpulan bahwa media Scrapbook Dongeng Fabel terhadap minat literasi siswa SD yang peneliti kembangkan mendapatkan kualitas sangat layak. Hal ini dibuktikan dengan persentase yang menunjukkan kriteria tersebut. Berdasarkan data kedua, hasil validasi materi menunjukkan jumlah persentase nilai rata-rata sebesar 84\% dari kedua ahli Berdasarkan hasil validasi materi, maka dapat disimpulan bahwa media Scrapbook Dongeng Fabel yang peneliti kembangkan mendapatkan kualitas sangat layak. Berdasarkan data ketiga, hasil validasi bahasa menunjukkan bahwa diperoleh jumlah persentase nilai rata-rata sebesar $74,15 \%$ dari kedua ahli, maka dapat disimpulan bahwa media Scrapbook Dongeng Fabel yang peneliti kembangkan mendapatkan kualitas layak. Berdasarkan uji validasi produk yang telah dilakukan kepada ketiga tim ahli, maka diperoleh nilai rata-rata produk secara keseluruhan yaitu sebesar 80,88\% dengan kategori "layak". Berdasarkan tabel data hasil respons siswa pada media Scrapbook Dongeng Fabel terhadap minat literasi siswa, maka diperoleh nilai akhir sebesar 93,3\% yang apabila diinterpretasikan telah mencapai kategori "Sangat Baik".

Berdasarkan hasil data diatas maka dapat peneliti jalaskan bahwa media Scrapbook dongeng fabel merupakan produk dari hasil penelitian dan pengembangan. Penelitian ini difokuskan pada pengembangan media Scrapbook terhadap penggunaan cerita dongeng dalam penerapan pembelajaran untuk melihat minat literasi baca tulis siswa sekolah dasar kelas rendah. Jenis Scrapbook yang peneliti kembangkan dalam penelitian ini adalah Scrapbook Dongeng Fabel untuk melihat minat literasi baca tulis siswa, perbedaan antara yang peneliti kembangkan dengan Scrapbook yang sudah ada sebelumnya adalah dari segi isi, materi pokok, dan sasaran pembaca. Jika Scrapbook yang pernah kembangkan lebih sering memuat materi Ilmu pengetahuan sosial, Ilmu Pengetahuan Alam atau materi pembelajaran lain yang isinya terstuktur untuk siswa SD kelas Tinggi, sedangkan media Scrapbook yang peneliti kembangkan ini dikhususkan untuk siswa SD kelas rendah yang berisikan cerita dongeng fabel untuk melihat minat literasi baca tulis mereka. Materi pokok yang dimuat pun difokuskan dengan memuat penggunaan kalimat penolakan, ajakan, serta penggunaan kata maaf dan tolong yang dituangkan di dalam cerita dongeng fabel dengan tujuan untuk memudahkan siswa dalam menggambarkan hidup rukun di masyarakat. Scrapbook Dongeng Fabel ini merupakan sarana pembelajaran yang dapat membantu guru untuk menarik minat siswa dalam kegiatan membaca dan menulis secara interaktif.

Hasil penelitian menyatakana bahwa media media Scrapbook yang dikembangkan layak digunakan dilihat dari aspek madia dan materi. Media yang dikembangkan sesuai kurikulum, materi dan karakteritik siswa akan membuat siswa belajar dan tentunya kan berdampak terhadap hasil belajarnya. Adanya media Scrapbook Dongeng Fabel membuat siswa belajar lebih baiik. Media Scrapbook merupakan media pembelajaran visual, karena dalam media Scrapbook menampilkan sebuah gambar untuk menarik minat baca siswa. Media visual sangat penting dibelajarkan kepada siswa dengan fungsi dapat memperlancar pemahaman dan memperkuat ingatan pada materi yang telah dibelajarkan oleh guru. Media pembelajaran yang unik dan menarik dibutuhkan untuk menumbuhkan minat literasi siswa yaitu dengan menggunakan media Scrapbook. Scrapbook merupakan salah satu seni menempel hiasan di atas kertas kemudian menghiasnya dengan karya yang kreatif (Saeful, 2017). 
Media Scrapbook sangat tepat diterapkan dalam pembelajaran, karena media Scrapbook meningkatkan keaktifan siswa dalam belajar sehingga akan menghasilkan suatu pembelajaran yang baik dan optimal (I. P. Sari et al., 2020). Penelitian ini sejalan dengan penelitian yang menyatakan bahwa Scrapbook merupakan sebuah media pembelajaran yang menggunakan teknik tempel guna menarik minat siswa dalam belajar (Utaminingsih et al., 2019). Minat memegang peranan yang sangat penting dalam kehidupan siswa dan berdampak besar pada sikap dan perilaku. Siswa yang tertarik pada kegiatan belajar akan berusaha lebih keras daripada siswa yang kurang tertarik untuk belajar(Aprijal et al., 2020; Nurfadilla \& Rosleny, 2018). Dengan kata lain minat belajar merupakan faktor pendorong siswa untuk belajar karena adanya minat akan menumbuhkan kesenangan dan kemauan siswa untuk belajar (Yunitasari \& Hanifah, 2020). Minat belajar mempengaruhi kualitas belajar siswa, minat belajar sebagai sebuah produk dan persepsi efikasi diri yang akan mempengaruhi motivasi siswa dalam proses belajar (Tamardiyah, 2017). Siswa dengan minat belajar yang tinggi pada akhirnya akan mencapai hasil belajar yang lebih baik daripada siswa dengan minat belajar yang rendah(Chen et al., 2020; Sirajuddin, 2018; Sulistyawati, 2020). Siswa yang tidak berminat terhadap bahan pelajaran akan menunjukan sikap kurang simpatik, malas dan tidak bergairah (Lisma et al., 2019). Minat yang tinggi akan membuat siswa lebih bersengat untuk belajar dan untuk memecahkan masalah yang diberikan. Meningaktnya literasi tidak terlapas dari media yang dikembangkan. minat membaca akan lebih tinggi karena penasaran pada materi yang dibelajarakan (Sari et al., 2019).

Penelitian ini sejalan dengan penelitian yang menyatakan bahwa Scrapbook merupakan sebuah media pembelajaran yang menggunakan teknik tempel guna menarik minat siswa dalam belajar (Utaminingsih et al., 2019). Penelitian serupa juga sejalan dengan penelitian yang menyatakan bahwa media pembelajaran Scrapbook disajikan dengan berisi materi-materi serta hiasan-hiasan guna menarik perhatian siswa, sehingga merangsang keinginan siswa dalam belajar (Suwandi, 2018). Penelitian yang menyatakan bahwa media media scrapbook berbasis picture and picture berorientasi wawasan kebangsaan telah valid, praktis dan efektif sehingga media ini dapat meningkatkan proses dan hasil belajar serta menanamkan wawasan kebangsaan sejak usia dini (Kasdriyanto \& Wardana, 2021). Penelitian yang menyatakan bahwa kualitas media scrapbook yang dikembangkan termasuk dalam kategori sangat layak dengan presentase 96,11\% dari 2 ahli materi, kategori sangat layak dengan presentase 85\% dari 2 ahli media, dan 94\% dari 2 ahli bahasa. Respon siswa terhadap media scrapbook pada uji coba dengan 17 responden sebesar 89,83\% dengan kategori sangat baik (Dewi \& Yuliana, 2018). Pada penelitian ini Scrapbook yang dikembangkan adalah Scrapbook Dongeng Fabel yang dikemas menjadi sebuah buku tempel yang unik dan menarik untuk dibaca, sehingga terciptanya kegiatan literasi yang menyenangkan karena dilakukan dengan bermain kreatif yang dimuat dalam media scrapbook tersebut. Kreatifitas yang dimuat dalam buku akan mendorong siswa untuk tertarik membacanya, hal ini menunjukan bahwa media pembelajaran Scrapbook sangat efektif digunakan khususnya dalam melatih siswa untuk mampu mengembangkan kreatifitasnya terutama dalam berbahasa seperti membaca dan menulis. Dengan adanya media pembelajaran Scrapbook juga dapat melatih siswa dalam berkomunikasi, bersosialisasi, serta dapat juga digunakan sebagai alat ukur untuk melihat ketertarikan siswa pada dunia literasi baca tulis.

\section{SIMPULAN}

Pengembangan media Scrapbook dongeng fabel terhadap minat literasi siswa SD yang telah dilakukan diciptakanya sebuah buku dongeng Scrapbook yang interaktif dan menarik. Selian itu media yang dikembangkan layak dengan katagori sangat baik dari aspek materi dan media. Oleh sebab itu bisa di rekomendasikan bahwa media Scrapbook Dongeng Fabel yang diahasilkan bisa digunakan sebagai salah satu alternative dalam pembelajaran.

\section{DAFTAR PUSTAKA}

Alfiah, A. N., Putra, N. M. D., \& Subali, B. (2018). Media Scrapbook Sebagai Jurnal Refleksi untuk Meningkatkan Kemampuan Kognitif dan Regulasi Diri. Jurnal Pendidikan (Teori Dan Praktik), 3(1), 57. https://doi.org/10.26740/jp.v3n1.p57-67.

Aprijal, A., Alfian, A., \& Syarifudin, S. (2020). Pengaruh Minat Belajar Siswa Terhadap Hasil Belajar Siswa di Madrasah Ibtidaiyah Darussalam Sungai Salak Kecamatan Tempuling. MITRA PGMI: Jurnal Kependidikan MI, 6(1), 76-91. https://doi.org/10.46963/mpgmi.v6i1.125.

Ayuningtyas, T. Y., \& Wijayaningsih, L. (2020). Efektivitas Permainan Detumbar (Dengarkan, Temukan gambar) terhadap Minat Belajar Anak Usia Dini. Jurnal Obsesi : Jurnal Pendidikan Anak Usia Dini, 5(1), 814. https://doi.org/10.31004/obsesi.v5i1.724.

Chen, D., Putri, N. D., Meliza, W., Astuti, Y., Wicaksono, L. Y., \& Putri, W. A. (2020). Identifikasi Minat Siswa SMA Kelas X Terhadap Mata Pelajaran Fisika. PENDIPA Journal of Science Education, 5(1), 36-39. https://doi.org/10.33369/pendipa.5.1.36-39.

Dewi, T. K., \& Yuliana, R. (2018). Pengembangan Media Pembelajaran Scrapbook Materi Karangan Deskripsi Mata 
Pelajaran Bahasa Indonesia Kelas Iii Sekolah Dasar. Refleksi Edukatika : Jurnal Ilmiah Kependidikan, 9(1). https://doi.org/10.24176/re.v9i1.2804.

Fiangga, S., Amin, siti M., Khabibah, S., Ekawati, R., \& Prihartiwi, nina rinda. (2019). Penulisan Soal Literasi Numerasi bagi Guru SD di Kabupaten Ponorogo. Jurnal Anugerah, 1(1), 9-18. https://doi.org/10.31629/anugerah.v1i1.1631.

Hanafi. (2017). Konsep Penelitian R\&D Dalam Bidang Pendidikan. Jurnal Kajian Keislaman, 4(2), 129-150. http://www.aftanalisis.com.

Indriyani, V., Zaim, M., Atmazaki, A., \& Ramadhan, S. (2019). Literasi Baca Tulis Dan Inovasi Kurikulum Bahasa. KEMBARA: Jurnal Keilmuan Bahasa, Sastra, Dan Pengajarannya, 5(1), 108. https://doi.org/10.22219/kembara.vol5.no1.108-118.

Kasdriyanto, D. Y., \& Wardana, L. A. (2021). Pengembangan Media Scrapbook Berbasis Picture And Picture Berorientasi Wawasan Kebangsaan. Jurnal Obsesi: Jurnal Pendidikan Anak Usia Dini, 6(1), 271-278. https://doi.org/10.31004/obsesi.v6i1.1255.

Lisma, E., Rahmadhani, R., \& Siregar, M. A. P. (2019). Pengaruh Kecemasan Terhadap Minat Belajar Matematika Siswa. ENLIGHTEN (Jurnal Bimbingan Dan Konseling Islam), 2(2), 85-91. https://doi.org/10.32505/enlighten.v2i2.1345.

Muslimin. (2018). Foster a Culture of Literacy Through Increased Reading. Cakrawala Pendidikan, 2. https://media.neliti.com/media/publications/237931-none-74db0b06.pdf.

Nasution, R. H., Hapidin, H., \& Fridani, L. (2020). Pengaruh Pembelajaran ICT dan Minat Belajar terhadap Kesiapan Membaca Anak Usia Dini. Jurnal Obsesi: Jurnal Pendidikan Anak Usia Dini, 4(2), 733. https://doi.org/10.31004/obsesi.v4i2.411.

Nurdiana, I., \& Murjainah. (2018). Hubungan Penggunaan Media Scrapbook Dengan Motivasi Belajar Geografi Siswa Kelas Vii Di Smp Negeri 41 Palembang. Edutech, 16(3), 274-287. https://doi.org/10.17509/e.v16i3.8079.

Nurfadilla, \& Rosleny. (2018). Hubungan Minat Baca Dengan Prestasi Belajar Ips Siswa Kelas V SD Gugus III Seyegan. Jurnal Kajian Pendidikan $\quad$ Dasar, 3(1), http://journal.unismuh.ac.id/index.php/jkpd/article/download/1173/1071.

Nurhab, M. irpan. (2018). Faktor-Faktor Yang Mempengaruhi Literasi Finansial Mahasiswa. Jurnal Akuntansi Dan Perbankan Syariah, 1(2), 255-274.

Pambudi, B. A. (2018). Hubungan Penggunaan Jaringan Internet, Pelayanan Administratif, Minat Dan Motivasi Belajar Dengan Prestasi Mahasiswa. Jurnal Manajemen Dan Supervisi Pendidikan, 2(3), 159-168. https://doi.org/10.17977/um025v2i32018p159.

Pangesti, fitraning tyas puji. (2018). Menumbuhkembangkan Literasi Numerasi Pada Pembelajaran Matematika Dengan Soal Hots. Indonesian Digital Journal of Mathematics and Education, 5(9), 566-575.

Pratiwi, siti habsari. (2021). Upaya Meningkatkan Literasi Membaca Di Masa Pandemi Melalui Kegiatan Seminggu Sebuku. $\quad$ Fitrah, 3(1), 27-48. https://journal.arraniry.ac.id/index.php/fitrah/article/download/835/556/.

Ratnasari, E. M. (2020). Outdoor Learning Terhadap Literasi Numerasi Anak Usia Dini. ThufuLA: Jurnal Inovasi Pendidikan Guru Raudhatul Athfal, 8(2), 182. https://doi.org/10.21043/thufula.v8i2.8003.

Rosihah, I., \& Pamungkas, A. S. (2018). Pengembangan Media Pembelajaran Scrapbook Berbasis Konteks Budaya Banten Pada Mata Pelajaran Ilmu Pengetahuan Sosial Di Sekolah Dasar. Muallimuna : Jurnal Madrasah Ibtidaiyah, 4(1), 35. https://doi.org/10.31602/muallimuna.v4i1.1405.

Sadli, M., \& Saadati, baiq arnika. (2019). Analisis Pengembangan Budaya Literasi Dalam Meningkatkan Minat Membaca Siswa Di Sekolah Dasar. TERAMPIL: Jurnal Pendidikan Dan Pembelajaran Dasar, 6(2), 151-164. https://doi.org/10.24042/terampil.v6i2.4829.

Saeful, A. R. (2017). Games Book sebagai Media Peningkatkan Minat Membaca pada Pembelajaran Indonseia SD Kelas Tinggi. Indonesian Journal of Primary Education, 1(1), 30. https://ejournal.upi.edu/index.php/IJPE/article/view/7494.

Sari, dwi arum, \& Supriyadi. (2021). Penguatan literasi budaya dan kewargaan berbasis sekolah di sekolah menengah pertama. 4(1), 13-17. https://doi.org/10.12928/citizenship.v4i1.19409.

Sari, I. P., Yuliantini, N., \& Tarmizi, P. (2020). Pengaruh Penggunaan Media Scrapbook terhadap Hasil Belajar pada Pembelajaran Tematik Siswa Kelas IV SD Gugus X Kota Bengkulu. Jurnal Riset Pendidikan Dasar, 3(1), 1-8. https://ejournal.unib.ac.id/index.php/juridikdasunib/article/download/14563/7147.

Sari, L. P., Patimah, S., \& Yusandika, A. D. (2019). Pengembangan Scrapbook Sebagai Media Pembelajaran Fisika. Indonesian Journal of Science and Mathematics Education, 2(2), 270-276. https://doi.org/10.24042/ijsme.v2i2.4367.

Setiawan, andika aldi, \& Sudigdo, A. (2019). Penguatan literasi siswa sekolah dasar melalui kunjungan perpustakaan. Prosiding Seminar Nasional PGSD, 2015, 27.

Setyaningsih, R., Abdullah, A., Prihantoro, E., \& Hustinawaty, H. (2019). Model Penguatan Literasi Digital Melalui Pemanfaatan E-Learning. Jurnal ASPIKOM, 3(6), 1200. https://doi.org/10.24329/aspikom.v3i6.333. 
Sirajuddin. (2018). Pengaruh Model Pembelajaran Kooperatif Dan Minat Belajar Siswa Terhadap Hasil Belajar Sejarah. Jurnal Ekonomi Efektif, 1(1), 64-83. https://doi.org/10.32493/JEE.v1i1.1982.

Suandewi, P. M., Putrayasa, I. B., \& Gunatama, G. (2019). Hubungan Budaya Literasi (Baca-Tulis) Dengan Hasil Belajar Bahasa Indonesia Siswa Kelas Xisma Negeri 7 Denpasar. Jurnal Pendidikan Bahasa Dan Sastra Indonesia Undiksha, 9(2). https://doi.org/10.23887/jjpbs.v9i2.20453.

Sulistyawati, E. (2020). Keefektifan pendekatan kontekstual berbasis budaya lokal ditinjau dari prestasi, minat belajar, dan apresiasi terhadap matematika. JP3M (Jurnal Penelitian Pendidikan Dan Pengajaran Matematika), 6(1), 27-42. https://doi.org/10.37058/jp3m.v6i1.1421.

Susanto, H. (2016). Membangun Budaya Literasi Dalam Pembelajaran Bahasa Indonesia Menghadapi Era MEA. JP-BSI Uurnal Pendidikan Bahasa Dan Sastra Indonesia), 1(1), 12. https://doi.org/10.26737/jpbsi.v1i1.70

Suwandi, S. (2018). Pembelajaran Bahasa Indonesia Yang Mencerdaskan Dan Tanggung Jawab Menghasilkan Generasi Literat. FON : Jurnal Pendidikan Bahasa Dan Sastra Indonesia, 13(2), 1-17. https://doi.org/10.25134/fjpbsi.v13i2.1562.

Tamardiyah, N. D. (2017). Minat Kedisiplinan dan Ketekunan Belajar terhadap Motivasi Berprestasi dan Dampaknya pada Hasil Belajar Matematika SMP. Manajemen Pendidikan, 12(1), 26. https://doi.org/10.23917/jmp.v12i1.2972.

Utaminingsih, S., Agustini, F., \& Aniq KHB, M. (2019). Pengembangan Media Scrap Book Tema 4 Berbagai Pekerjaan Subtema 3 Pekerjaan Orang Tuaku. Jurnal Penelitian Dan Pengembangan Pendidikan, 3(2), 64. https://doi.org/10.23887/jppp.v3i2.17378.

Utomo, H. N., Arifin, I., \& Timan, A. (2018). Latar Minat \& Animo Peserta Didik Dalam Pembelajaran Berbasis Proyek Di Sekolah Menengah Kejuruan 4 Tahun. Jurnal Administrasi Dan Manajemen Pendidikan, 1(1), 45-51. https://doi.org/10.17977/um027v1i12018p45.

Wijaya, E. Y., Sudjimat, D. A., \& Nyoto, A. (2016). Transformasi Pendidikan Abad 21 Sebagai Tuntutan. Jurnal Pendidikan, 1, 263-278.

Yunitasari, R., \& Hanifah, U. (2020). Pengaruh Pembelajaran Daring terhadap Minat Belajar Siswa pada Masa COVID 19. Edukatif: Jurnal Ilmu Pendidikan, 2(3), 236-240. https://doi.org/10.31004/edukatif.v2i3.142.

Yusuf, R., Sanusi, Razali, Maimun, Putra, I., \& Fajri, I. (2020). Tinjauan Literasi Budaya dan Kewargaan Siswa SMA Se-Kota Banda Aceh. Jurnal Pendidikan Kewarganegaraan Undiksha, 8(2), 91-99. https://ejournal.undiksha.ac.id/index.php/JJPP/article/view/24762. 